\title{
Raw cassava rhizome waste as a binder in sugarcane bagasse and straw briquettes
}

\section{Andrea Cressoni De Conti ( $\nabla$ andrea.cressoni@unesp.br)}

Sao Paulo State University Julio de Mesquita Filho: Universidade Estadual Paulista Julio de Mesquita Filho https://orcid.org/0000-0002-5433-3295

\section{Marcos Paulo Patta Granado}

Sao Paulo State University Julio de Mesquita Filho: Universidade Estadual Paulista Julio de Mesquita Filho

\section{Elias Ricardo Durango Padilla}

Federal University of Sao Carlos: Universidade Federal de Sao Carlos

\section{Gabriela Tami Nakashima}

Federal University of Sao Carlos: Universidade Federal de Sao Carlos

\section{Cláudio De Conti}

Sao Paulo State University Julio de Mesquita Filho: Universidade Estadual Paulista Julio de Mesquita Filho

\section{Fábio Minoru Yamaji}

Federal University of Sao Carlos: Universidade Federal de Sao Carlos

\section{Research Article}

Keywords: Bioenergy, Biomass, Densification, waste, Brazil, agriculture

Posted Date: March 11th, 2021

DOl: https://doi.org/10.21203/rs.3.rs-278278/v1

License: (c) (i) This work is licensed under a Creative Commons Attribution 4.0 International License.

Read Full License

Version of Record: A version of this preprint was published at BioEnergy Research on July 8th, 2021. See the published version at https://doi.org/10.1007/s12155-021-10300-5. 


\title{
Raw cassava rhizome waste as a binder in sugarcane bagasse and straw briquettes
}

Andrea Cressoni De Conti ${ }^{\mathrm{a}, 1,{ }^{*}}$, Marcos Paulo Patta Granado ${ }^{\mathrm{a}, 2}$, Elias Ricardo Durango Padilla ${ }^{\mathrm{b}, 3}$, Gabriela Tami Nakashima ${ }^{\text {c,4 }}$, Cláudio De Conti ${ }^{\text {a,5 }}$, Fábio Minoru Yamaji c,6

${ }^{a}$ Department of Energy Engineering, BioJoule - Biomass Densification Laboratory, Department of Energy Engineering, São Paulo State University (Unesp), Campus of Rosana, 19274-000, Rosana, SP, Brazil.

b Department of Mechanical Engineering, São Paulo State University, 12516-410, Guaratinguetá, SP, Brazil. ${ }^{\mathrm{c}}$ Department of Environmental Sciences, Federal University of São Carlos, 18052-780, Sorocaba, SP, Brazil. ${ }^{1}$ ORCID ID: 0000-0002-5433-3295

${ }^{2}$ ORCID ID: 0000-0002-1466-7565

${ }^{3}$ ORCID ID: 0000-0001-5864-8828

${ }^{4}$ ORCID ID: 0000-0001-7437-4521

${ }^{5}$ ORCID ID: 0000-0002-3024-2671

${ }^{6}$ ORCID ID: 0000-0002-0908-8163

*Corresponding author: andrea.cressoni@unesp.br

\begin{abstract}
The objective of this study was to analyze the cassava rhizome as a natural binder in blend briquettes from cassava rhizome, bagasse, and sugarcane straw. For this study, $20 \mathrm{~kg}$ of material (cassava rhizome sugarcane bagasse and straw) were dried to a moisture content closer to $12 \%$. Six treatments were used for briquette production. Three blends and three $100 \%$ materials (without mix) were analyzed. The briquettes were produced in a lab-scale press with heating $\left(120^{\circ} \mathrm{C}\right)$. The results showed that the energy index comparison varied from 6.20-8.25. The fracture limit for the resistance compressive test and the ultimate strength of the briquettes were found for B6 (100\% cassava rhizome), followed by the B2 blend ( $75 \%$ cassava rhizome $+15 \%$ bagasse $+10 \%$ straw). Treatment B2 was the best composition for an energy source by proximate analysis. All treatments (briquettes) had a durability closer to $97 \%$. Scanning electron microscopy (SEM) and energy dispersive spectroscopy (EDS) revealed the presence of $\mathrm{Ca}, \mathrm{K}$, and $\mathrm{Si}$. The raw cassava rhizome behaves like a natural binder, and treatment B2 was the best blend for briquette production.
\end{abstract}

Keywords: Bioenergy, Biomass, Densification, waste, Brazil, agriculture. 


\section{INTRODUCTION}

The economic development of a country is strongly linked to energy consumption and signifies industrialization [1], [2]. After the industrial revolution, the world economy was primarily based on fossil fuel energy matrices, such as oil and coal [3], which cause emissions of pollutants and greenhouse gases that have impacts, such as climate change and global warming [4]-[6]. The rethinking of alternative energy sources was necessary, and renewable energies have grown in recent years.

In 2019, the Brazilian Energy Balance (BEN) consisted of 45.3\% renewable energy sources for domestic energy supply. One of the most important renewable energy sources, sugarcane biomass (17.4\%), surpassed the participation of hydraulic (12.6\%) and natural gas (12.5\%) in the energy matrix [7].

The primary source of biomass in Brazil used for electricity generation is sugarcane bagasse; the 2020/2021 harvest is projected to be 642 million tons [8]. Sugarcane straw and other agricultural residues have been studied and used for the generation of thermal or electrical energy [3], [9], [10].

One way to make better use of this waste for energy generation is to use energy densification, a process in which the raw material is compacted to obtain a product (briquettes or pellets) with higher density $\left(\mathrm{kg} / \mathrm{m}^{3}\right)$ and higher energy density $\left(\mathrm{kJ} / \mathrm{m}^{3}\right)$ than the initial raw material. This process is primary used for low-density materials, such as agricultural and agro-industrial residues, such as sawdust, rice husks, and sugarcane bagasse [11], [12]. With the increase in density, the process also improves the transportation and storage of these materials [3], [9], [10], [14].

Bajwa et al. [15] conducted a study on the production of briquettes for energy generation, found that production increased in the last decade and is expected to increase by 56\% from 2010-2040, and pointed out that agricultural waste is an ideal candidate for densification because of the large volumes of biomass produced. The low density of agricultural residue allows easy transport and handling. The use of densified agricultural waste for energy production can reduce dependence on fossil fuels, and densified products can be effectively used to produce heat and energy.

The pellets are formed by the extrusion process and have high density and a cylindrical size of $38 \mathrm{~mm}$ (1.5 in.) and diameter of $7 \mathrm{~mm}$ (0.3 in.). Briquettes differ from pellets by size, maintaining a cylindrical shape with a diameter of approximately $25 \mathrm{~mm}$ (2 in) [16]. The biomass material must be characterized for energy densification; characterization is primarily based on the following analyses: elementary chemical composition, immediate composition, and calorific power. The briquette quality can also be measured by mechanical resistance and durability tests. 
Several papers on biomass characterization have been published to improve and optimize densification through briquetting [4], [17]-[26]. Felfli et al. [20], conducted a study on the state of biomass briquetting and its prospects in Brazil to determine the availability and characteristics of agro-waste products for briquetting. They found that wood residues, rice husks, and coffee husks are the most promising agro-residues for shortterm briquetting in Brazil.

Biomass briquettes have great potential for use as solid fuels. However, the formation of briquettes depends on the biomass characteristics. For example, some types of biomass (grass) are not easily compacted, and binders may be necessary for good formation. However, the use of a binder makes the process more difficult and expensive [25], [27]-[32].

Although densification began using residues from the wood industry [33], agricultural residues have also begun to be studied, and various blends (mixtures) have been tested. Silva et al. [6] analyzed four biomass types: sawdust from Eucalyptus sp. and Pinus sp., bagasse, and sugarcane straw, all of which were viable for the densification process, which was influenced by granulometry.

Nurek et al. [34] studied the effects of temperature and pressure on the manufacture of crushed wood residue briquettes and concluded that a useful compaction index and durability coefficient were obtained for a temperature of $73{ }^{\circ} \mathrm{C}$ and moisture content of $10 \%$. According to Gilvari et al. [35], density and durability are the most significant factors for determining the physical quality of densified materials.

The objective of this study was to analyze the energetic densification of bagasse, sugarcane straw, and cassava rhizome. The specific objective was to verify the effect of addition of the cassava rhizome on briquette quality (improved mechanical resistance and energy properties).

\section{MATERIAL AND METHODS}

\subsection{Material}

The materials used were cassava rhizome, sugarcane bagasse and straw. Approximately $20 \mathrm{~kg}$ of each type of residue was collected in Rosana, São Paulo state, Brazil. Sugarcane bagasse and straw were collected at an industrial site located at $22^{\circ} 31^{\prime} 57^{\prime \prime S} 52^{\circ} 10^{\prime} 03^{\prime \prime} \mathrm{W}$, whereas the cassava rhizome was collected at a settlement located at $22^{\circ} 25^{\prime} 36.9^{\prime \prime} \mathrm{S} ; 52^{\circ} 48^{\prime} 22.3^{\prime \prime} \mathrm{W}$. The materials were dried $(<12 \%)$ in a laboratory oven, based on [36]. 
The dried material was ground in a knife mill before storage. The standard CEN/TS 15149-2 [37] was used to analyze particle size distribution. The particle size was chosen by the particles passed through a sieve with an aperture of 20 mesh $(0,850 \mathrm{~mm})$ and remained in a sieve with an aperture of $40 \mathrm{mesh}(0,425 \mathrm{~mm})$. After determining the granulometry, the materials were blended according to Table 1.

\section{Table 1. Treatments for briquette production}

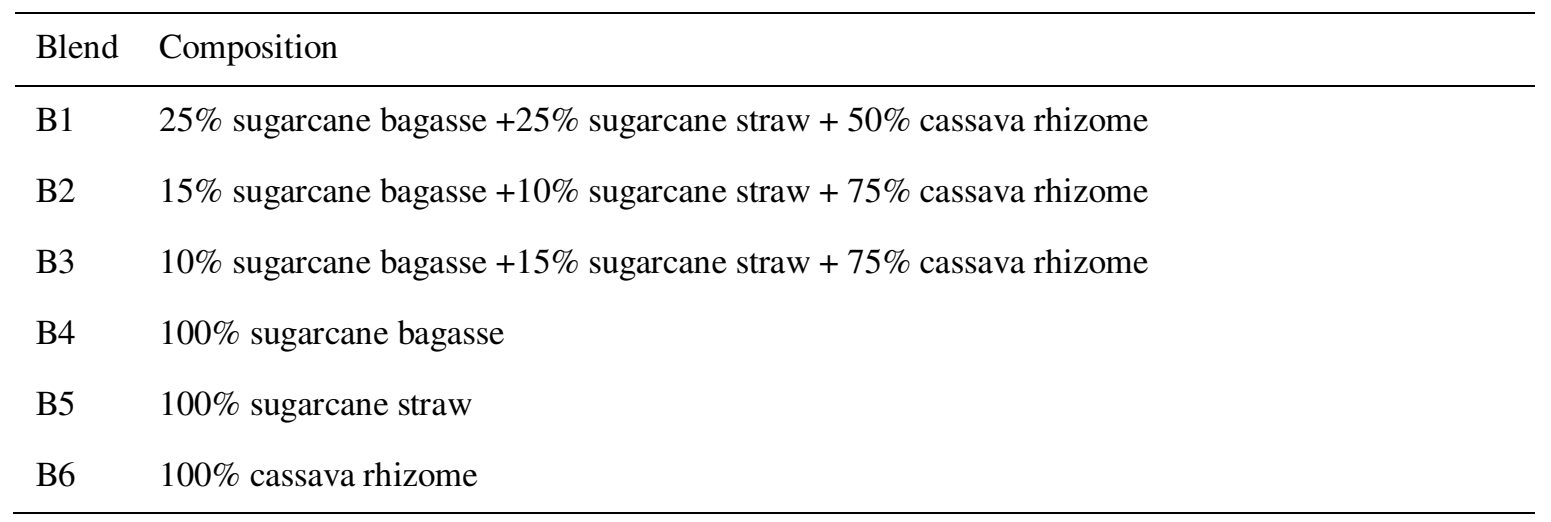

\subsection{Proximate analysis and higher heating value}

Proximate analysis and higher heating value (HHV) were determined for the raw materials. The analyses were performed using the American Society for Testing and Materials (ASTM). Proximate analysis determines the moisture content (ASTM D-3173 [36]), volatile matter (MV) - ASTM D3175 [38], ash content (AC) - ASTM D-3173 [36] and fixed carbon (FC) calculated by equation (1). The HHV analysis was performed using a calorimeter (IKA C200), following ASTM D2015-96.

$$
F C(\%)=100-(A C(\%)+M V(\%))
$$

\subsection{Densities}

\subsubsection{Bulk density}

The bulk density was determined for the bagasse, straw, and cassava rhizome raw materials. The E87382 standard was used to analyze the bulk density [39]. A $1000 \mathrm{ml}$ measuring cylinder was used to measure the sample volume, and a semi-analytical balance was used to measure the corresponding mass to obtain the density by mass/volume fraction (Equation 2). 


$$
\rho=\frac{m}{v}
$$

where $\rho$ is the bulk density $\left(\mathrm{kg} / \mathrm{m}^{3}\right) ; m$ is the mass $(\mathrm{kg}) ; v$ is the volume $\left(\mathrm{m}^{3}\right)$.

\subsubsection{Apparent density}

Apparent density was determined for the briquettes (after compaction of raw materials). Apparent density gives the ratio between mass and volume after briquette manufacturing. (Equation 3).

$$
\rho_{a}=\frac{m}{v}
$$

where $\rho_{a}$ is the apparent density $\left(\mathrm{kg} / \mathrm{m}^{3}\right), m$ is the mass $(\mathrm{kg})$, and $v$ is the volume $\left(\mathrm{m}^{3}\right)$.

\subsubsection{Energy apparent density}

Equation (4) gives the energy apparent density of the briquettes.

$$
\rho_{e}=\rho_{a} * H H V
$$

where $\rho_{e}$ is the energy apparent density $\left(\mathrm{MJ} / \mathrm{m}^{3}\right) ; \rho_{a}$ is the apparent density $\left(\mathrm{kg} / \mathrm{m}^{3}\right)$; and $H H V-$ Higher heating value $(\mathrm{MJ} / \mathrm{kg})$.

\subsubsection{Energy bulk density}

The energy bulk density (raw material) was calculated according to equation (5).

$$
\rho_{e a}=\rho * H H V
$$

where $\rho_{e a}$ is the energy bulk density $\left(\mathrm{MJ} / \mathrm{m}^{3}\right), \rho$ is the bulk density $\left(\mathrm{kg} / \mathrm{m}^{3}\right)$, and $H H V$ is the higher heating value $(\mathrm{MJ} / \mathrm{kg})$.

\subsection{Energy comparison index}

The value of the energy in the briquette can be obtained by comparing the energy from the energy bulk density and the energy apparent density. This index is called the energy comparison index $\left(I \rho_{e}\right)($ Equation $6)$. 


$$
I \rho_{e}=\frac{\rho_{e}}{\rho_{e a}}
$$

where $\rho_{e \boldsymbol{a}}$ is the energy bulk density $\left(\mathrm{MJ} / \mathrm{m}^{3}\right)$, and $\rho_{\boldsymbol{e}}$ is the energy apparent density $\left(\mathrm{MJ} / \mathrm{m}^{3}\right)$.

\subsection{Briquettes: Volumetric expansion and physical tests}

Fifty grams of material was used per briquette for production. A lab-scale press model LB32 with a pressure of $100 \mathrm{bar}$, heating temperature of $120^{\circ} \mathrm{C}$, pressing time of $5 \mathrm{~min}$, and cooling time of $7 \mathrm{~min}$ was used. Fifteen briquettes were produced for each blend. Five pieces (briquettes) were used for the mechanical resistance test, and 10 briquettes were used for the durability test.

Additionally, volumetric expansion was determined by measuring the height and width of the briquettes with a caliper $1,3,5,7,24,48$, and $72 \mathrm{~h}$ after confection. The briquette volume was calculated using equation (7)

$$
V=\pi r^{2} h
$$

where $V$ is the briquette volume $(\mathrm{cm}), r$ is the cylinder circumference radius $(\mathrm{cm})$, and $h$ is the briquette height $(\mathrm{cm})$,

The variation of this expansion is given by equation (8):

$$
\Delta V=\frac{V_{2}-V_{1}}{V o l 1} 100
$$

where $\Delta V$ is the volumetric expansion of the briquettes (\%), $V_{1}$ is the briquette volume immediately after compression $\left(\mathrm{cm}^{3}\right)$, and $V_{2}$ is the volume of the briquettes after a certain time after compaction $\left(\mathrm{cm}^{3}\right)$.

\subsection{Resistance to compression}

After manufacturing, the mechanical resistance test was performed using the ABNT NBR 7222/2011 [40] standard. The test was performed in a universal machine of mechanical tests with a load cell of $5 \mathrm{kN}$ (EMIC model DL30000) and load speed of $3 \mathrm{~mm} / \mathrm{min}$ [41]. 
The maximum stacking height for each treatment was calculated from the test results. Equations (9) and (10) show the number of samples stacked (Nemp) and stacking height (Hemp) [6], respectively.

$$
N_{e m p}=\frac{F_{r u p}}{f_{s} * 0,020}
$$

where $N_{\text {emp }}=$ Number of samples stacked; $F_{\text {rup }}=$ Breaking strength; $f_{s}=$ safety factor $\left(f_{s}=300 \%[6]\right)$

$$
H_{e m p}=\frac{N_{e m p} * D}{100}
$$

where;

$H_{e m p}=$ Stacking height;

$D=$ Briquette diameter .

\subsection{Durability}

The durability test followed the standard CEN/TS15210-2 [37]. The equipment used was the rollerdrum KT3010 with five repetitions. Two briquettes were used in the drummer, for a total of $100 \mathrm{~g}$ with 105 rotations per test. Finally, the briquette pieces were passed through a 6-mesh screen, and the retained pieces were weighed. The durability was calculated using equation (11):

$$
D U=\frac{m_{f}}{m_{i}} 100
$$

where $D U$ is the briquette durability $(\%), m_{i}$ is the initial mass of the briquettes before the test $(\mathrm{g})$, and $m_{f}$ is the final mass of the briquette pieces after the test $(\mathrm{g})$. 


\subsection{Scanning electron microscopy (SEM) and energy dispersive spectroscopy (EDS)}

A scanning electron microscope (SEM) HITACHI model TM 3000 was used to analyze the ash from the blends. The chemical analyses were verified by X-ray energy dispersive spectroscopy (EDS) coupled to the equipment.

\subsection{Statistical analysis}

The data obtained were subjected to ANOVA and Tukey's comparative test (with 95\% significance) using the R statistical software.

\section{RESULTS AND DISCUSSION}

\subsection{Moisture content}

After oven drying, all materials (bagasse, straw, and cassava rhizome) were kept at room temperature until moisture content equilibrium was achieved (10-12\%). According to Bajwa et al.[15], the natural moisture content of the material in the densification process should be between $10 \%$ and $15 \%$. Other authors, such as Castellano et al.[42], conducted a quality study of pellets made with wood and other biomass and mentioned that the moisture contents of the materials were between $10 \%$ and $12 \%$. Wang et al. [43], studied the briquetting process for rice straw with a moisture content of approximately $15 \%$.

\subsection{Density}

Table 2 presents the material density and energy density data before the briquetting process and after the process application and the energy comparison index.

Table 2. Bulk Density $\boldsymbol{\rho}\left(\mathrm{kg} / \mathrm{m}^{3}\right)$ and Energy Bulk Density $\boldsymbol{\rho}_{\boldsymbol{e}}\left(\mathrm{MJ} / \mathrm{m}^{3}\right)$, Apparent Density $\boldsymbol{\rho}_{\boldsymbol{a}}\left(\mathrm{kg} / \mathrm{m}^{3}\right)$ and Energy Apparent Density $\boldsymbol{\rho}_{\boldsymbol{e}}\left(\mathrm{MJ} / \mathrm{m}^{3}\right)$, and Energy Comparison Index $\boldsymbol{I} \boldsymbol{\rho}_{\boldsymbol{e}}$.

\begin{tabular}{cccccc}
\hline Blend & $\boldsymbol{\rho}\left(\mathrm{kg} / \mathrm{m}^{3}\right)$ & $\boldsymbol{\rho}_{\boldsymbol{e} \boldsymbol{a}}\left(\mathrm{MJ} / \mathrm{m}^{3}\right)$ & $\boldsymbol{\rho}_{\boldsymbol{a}}\left(\mathrm{kg} / \mathrm{m}^{3}\right)$ & $\boldsymbol{\rho}_{\boldsymbol{e}}\left(\mathrm{MJ} / \mathrm{m}^{3}\right)$ & $\boldsymbol{I} \boldsymbol{\rho}_{\boldsymbol{e}}$ \\
\hline B1 & $192 \pm 3$ & $3237 \pm 45$ & $1246 \pm 16$ & $21556 \pm 175$ & 6.66 \\
B2 & $195 \pm 2$ & $3235 \pm 35$ & $1254 \pm 12$ & $21144 \pm 163$ & 6.54
\end{tabular}


The results showed that B2 briquettes with values of $1254 \mathrm{~kg} / \mathrm{m}^{3}\left(1.25 \mathrm{~g} / \mathrm{cm}^{3}\right)$ and B5 briquettes with values of $1257 \mathrm{~kg} / \mathrm{m}^{3}\left(1.26 \mathrm{~g} / \mathrm{cm}^{3}\right)$ present apparent density higher than the values obtained by Banaag et al [44] and Obi et al. [45]. Apparent energy density increased with respect to bulk energy density, because the presented energy comparison index $\left(I \rho_{e}\right)$ varied from 6.20 to 8.25. The most significant increase for the $100 \%$ pure materials was obtained for $\mathrm{B} 4$, whereas the highest blended value was for $\mathrm{B} 1$.

The density of a material is linked to handling, transport, and storage. Thus, the briquetting process causes high density solids to be manufactured with these materials and improves the above-mentioned variables (Bajwa et al., 2018, Gilvari et al., 2019). Banaag et al. [44] produced briquettes from sugarcane bagasse and rice bran at a temperature of $150{ }^{\circ} \mathrm{C}$ during a pressing time of $30 \mathrm{~min}$ and a pressing ratio of $0.34 \mathrm{MPa} / \mathrm{s}$ and verified that the density was $1.194 \mathrm{~g} / \mathrm{cm}^{3}$. Obi et al. [45], evaluated briquettes made with sawdust mixed with cassava starch as a binder prepared in proportions of 100:15, 100:25, 100:35, and 100:45 by weight and obtained a compacted density of $0.727 \mathrm{~g} / \mathrm{cm}^{3}$. The optimal mixing ratio based on calorific power was reached at a mixture ratio of 100:35 with a compacted density of $0.703 \mathrm{~g} / \mathrm{cm}^{3}$.

\subsection{Volumetric expansion}

The volumetric expansions are presented in Table 3 and Figure 1.

Table 3. Volumetric Expansion

\begin{tabular}{cc}
\hline Treatment & $\boldsymbol{\Delta} \boldsymbol{V}(\%)$ \\
\hline B1 & 6.05 \\
B2 & 6.65 \\
B3 & 6.83 \\
B4 & 4.61 \\
B5 & 6.92 \\
B6 & 4.48 \\
\hline
\end{tabular}




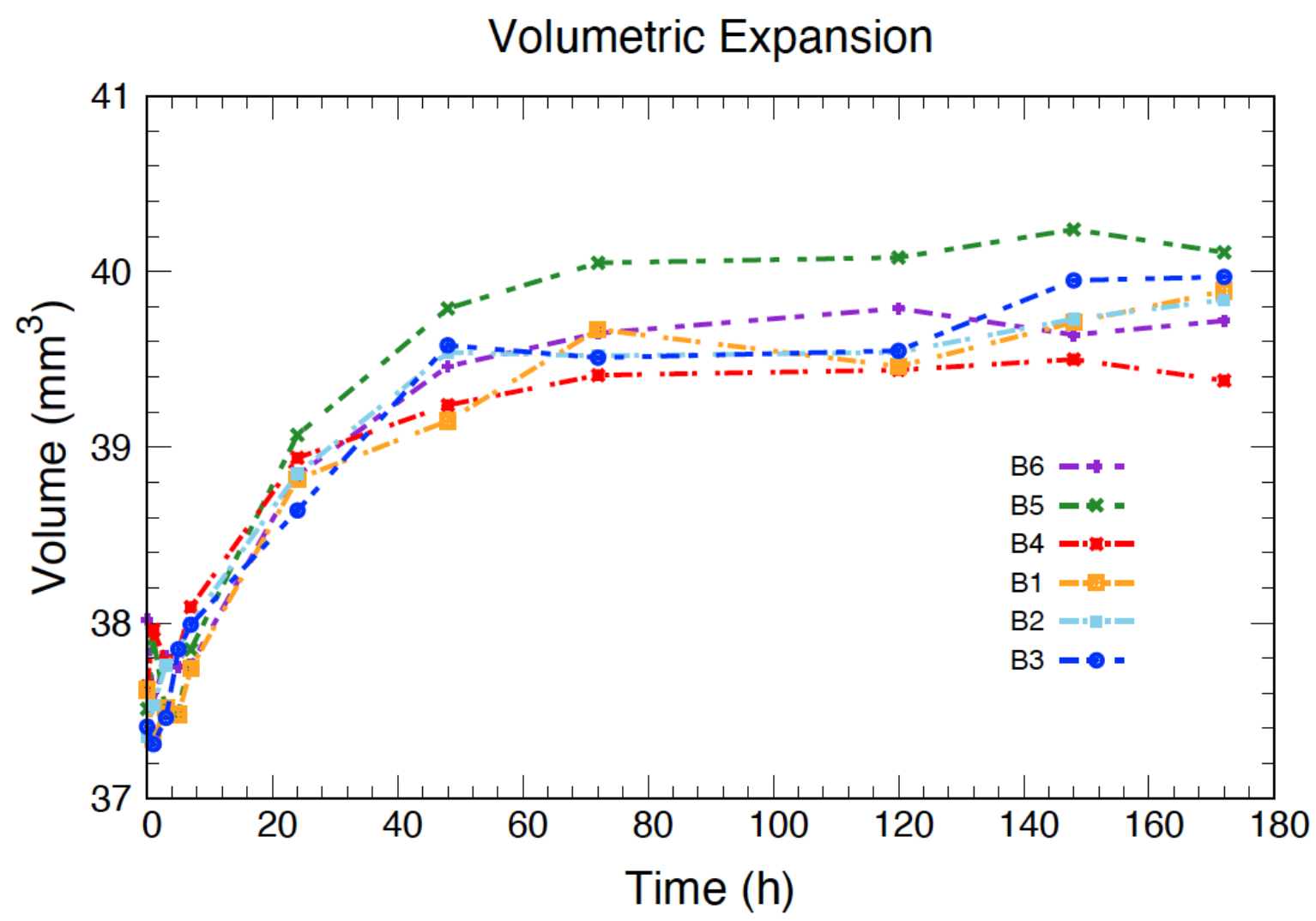

Figure 1. Volumetric Expansion of the briquettes formed by treatment.

Figure 1 shows that the briquettes of all blends presented a significant expansion between 7 and 48 $\mathrm{h}$ after their confection and tended to stabilize their volumetric variation after $72 \mathrm{~h}$.

Treatment B5 presented the largest volumetric expansion, whereas the smallest expansion occurred for B6. The blends (B1-B3) showed a volumetric expansion of approximately 6\%. This expansion did not affect briquette formation.

\subsection{Compression test}

The compression test resistance results are presented in Table 4.

Table 4. Resistance to compression test, fracture limit, ultimate strength and stacking height $\left(\mathrm{H}_{\mathrm{emp}}\right)$

\begin{tabular}{ccccc}
\hline Blend & $\begin{array}{c}\text { Fracture } \\
\text { Limit (kgf) }\end{array}$ & $\begin{array}{c}\text { Ultimate strength } \\
(\mathrm{MPa})\end{array}$ & $\mathrm{N}_{\mathrm{emp}}$ & $\begin{array}{c}\mathrm{H}_{\mathrm{emp}} \\
(\mathrm{m})\end{array}$ \\
\hline B1 & 510.8 & 2.00 & 3737 & 123 \\
B2 & 674.4 & 2.65 & 4496 & 148
\end{tabular}




\begin{tabular}{lllll}
\hline B3 & 499.3 & 1.95 & 3328 & 109 \\
B4 & 484.7 & 1.85 & 3231 & 109 \\
B5 & 286.6 & 1.1 & 1910 & 66 \\
B6 & 591.2 & 2.3 & 5252 & 178 \\
\hline
\end{tabular}

According to Gilvari et al. [35] and [46], a compression intensity is a way of verifying how the briquettes behave during transport and storage. Martinez et al. [47] studied the mechanical resistance of briquettes made with coffee and pinewood residue to obtain fracture limits from 415 to $569 \mathrm{kgf}$. Silva et al. [6], studied sugarcane bagasse and straw briquettes and found resistance of 0.270 and $0.975 \mathrm{MPa}$, fracture limit (tensile strength) of 35.09 and $100.70 \mathrm{kgf}$, and stacking height values of; 20 and $59 \mathrm{~m}$, respectively.

The fracture limit (tensile strength) is approximately 286.6 to $674.4 \mathrm{kgf}(1 \mathrm{kgf}=9.8 \mathrm{~N})$ and the strength ranges from 1.1to $2.65 \mathrm{MPa}$ (Table 4). The cassava rhizome (B6) material was the strongest treatment, followed by B2 (composition of $75 \%$ of cassava rhizome). Analysis of sugarcane bagasse and straw materials revealed lower resistances and addition of the cassava rhizome to blend B2 increased the resistance by $39 \%$ and $135 \%$ compared to that of sugarcane bagasse and sugarcane straw, respectively. Thus, the insertion of raw cassava rhizomes increases the resistance of briquettes composed of bagasse and straw, and cassava rhizome acts as a binder in the compaction process of the sugarcane bagasse and straw briquettes. Blend B2 had the highest stacking height.

\subsection{Proximate analysis and higher heating value}

The values of the volatile matter (TV), ash content (TC), fixed carbon content (TCF), higher heating value (HHV) and the comparisons with other studies are presented in Table 5.

Table 5. Results found for volatile matter (TV), ash content (TC), fixed carbon content (TCF), higher heating value (HHV) and literature values for comparison.

\begin{tabular}{|c|c|c|c|c|c|c|c|c|}
\hline Blend & $\mathrm{TV}(\%)$ & $\begin{array}{l}\text { TV }(\%) \\
\text { [referenc } \\
\text { e] }\end{array}$ & $\begin{array}{l}\mathrm{TC} \\
(\%)\end{array}$ & $\begin{array}{l}\mathrm{TC}(\%) \\
\text { [reference] }\end{array}$ & $\begin{array}{l}\text { TCF } \\
(\%)\end{array}$ & $\begin{array}{l}\text { TCF }(\%) \\
\text { [reference] }\end{array}$ & $\begin{array}{l}\text { HHV } \\
(\mathrm{MJ} / \mathrm{kg})\end{array}$ & $\begin{array}{l}\text { HHV } \\
(\mathrm{MJ} / \mathrm{kg}) \\
\text { [reference] }\end{array}$ \\
\hline B1 & $\begin{array}{l}79.11 \\
\pm 0.31 \mathrm{ab}\end{array}$ & - & $\begin{array}{l}5.81 \\
\pm 0.08 \\
\text { bc }\end{array}$ & - & $\begin{array}{l}15.09 \\
\pm 0.39 \\
\text { abc }\end{array}$ & - & $\begin{array}{l}16.864 \pm \\
250\end{array}$ & - \\
\hline
\end{tabular}




\begin{tabular}{|c|c|c|c|c|c|c|c|c|}
\hline B2 & $\begin{array}{l}76.86 \\
\pm 0.53 \mathrm{bc}\end{array}$ & - & $\begin{array}{l}7.35 \\
\pm 0.26 \\
\text { ab }\end{array}$ & - & $\begin{array}{l}15.80 \pm \\
0.30 \mathrm{ab}\end{array}$ & - & $\begin{array}{l}16.586 \\
\pm 220\end{array}$ & - \\
\hline B3 & $\begin{array}{l}77.27 \\
\pm 0.94 \mathrm{bc}\end{array}$ & - & $\begin{array}{l}8.14 \\
\pm 1.03 \\
\mathrm{ab}\end{array}$ & - & $\begin{array}{l}14.59 \\
\pm 0.49 \mathrm{bc}\end{array}$ & - & $\begin{array}{l}17.516 \\
\pm 380\end{array}$ & - \\
\hline B4 & $\begin{array}{l}81.60 \\
\pm 0.83 \mathrm{a}\end{array}$ & $\begin{array}{l}80.69^{1} \\
79.9^{3}\end{array}$ & $\begin{array}{l}6.69 \\
\pm 0.52 \\
\text { abc }\end{array}$ & $\begin{array}{r}1.42^{1} \\
2.2^{3}\end{array}$ & $\begin{array}{l}11.71 \\
\pm 0.42 \mathrm{~d}\end{array}$ & $\begin{array}{l}17.89^{1} \\
18.99^{3}\end{array}$ & $\begin{array}{l}17.800 \\
\pm 140\end{array}$ & $\begin{array}{l}18.540^{1} \\
18.100^{3}\end{array}$ \\
\hline B5 & $\begin{array}{l}81.60 \\
\pm 0.29 \mathrm{a}\end{array}$ & $\begin{array}{l}77.50^{2} \\
84.5^{3}\end{array}$ & $\begin{array}{l}4.57 \\
\pm 0.17 \mathrm{c}\end{array}$ & $\begin{array}{l}12.19^{1} \\
2.7^{3}\end{array}$ & $\begin{array}{l}13.83 \\
\pm 0.20 \mathrm{c}\end{array}$ & $\begin{array}{l}17.22^{1} \\
11.6^{3}\end{array}$ & $\begin{array}{l}16.879 \\
\pm 250\end{array}$ & $\begin{array}{l}15.630^{1} \\
17.400^{3}\end{array}$ \\
\hline B6 & $\begin{array}{l}74.79 \pm \\
0.25 c\end{array}$ & $86.52^{4}$ & $\begin{array}{l}8.65 \\
\pm 0.46 \mathrm{a}\end{array}$ & $2.79^{4}$ & $\begin{array}{l}16.56 \pm \\
0.37 \mathrm{a}\end{array}$ & $10.69^{4}$ & $\begin{array}{l}16.263 \\
\pm 200\end{array}$ & $18.950^{4}$ \\
\hline
\end{tabular}

Different letters show significant difference between samples with 5\% significance in Tukey test.

${ }^{1}[6] ;{ }^{2}[19] ;{ }^{3}[49] ;{ }^{4}[48]$

The results for TV agree with the literature (Da Silva et al., 2015, Leal et al., 2013, D. Padilla et al., 2016, Veiga, 2012). The difference for the TV of the cassava rhizome was $13,55 \%$ less compared to results presented by Veiga et al. [48]. It can be explained by the feedstock pre-treatment (wash) for the biomasses used by Veiga et al [48]. In this study, washing was not used (only sieving). Thus, contaminants, such as soil, must have remained next to the materials and altered the values [50].

No significant change among values was obtained for blends B1, B2 and B3. The results showed that the addition of $50-75 \%$ cassava rhizomes to the blends did not change the TV content.

The TC values obtained for B4 and B5 agree with the literature (Da Silva et al., 2015, Leal et al., 2013, Gilvari et al., 2019). The TC of cassava (B6) was 3.1 times higher than that obtained by Veiga et al.[48], because the material was not washed. For the blends, the lowest TC was observed for B1. Blend B1 contains $50 \%$ cassava rhizome, whereas B2 and B3 contain 75\% cassava rhizome. The results show that the blending process is efficient.

The TCF value obtained for straw (B5) agrees with Silva et al.[6] and Leal et al. [49]. For bagasse B4, the FC was lower than those found by [6] and [49], because of the difference in ash content. The impurities (sand and soil) in the material increased the ash content and influenced this value [50]. B6 presented a fixed 
carbon content larger than the value found by Veiga et al. [48], indicates that this blend is very resilient during the combustion process.

The HHV is the amount of heat that the material provides. The values for B4 and B5 agree with those by Silva et al. [6] and Leal et al. [49]. The B6 value is $14 \%$ below that found by Veiga et al. [48]. The lack of a washing process should be responsible for decreasing the HHV. Blend 3 had the highest HHV of the blends.

According to the obtained results, it is possible to determined that blend 2 has the best composition for using the material as an energy source because of the high TCF value. which characterizes a longer burning time and presents good TV, which characterizes good ignition power, burning and HHV.

\subsection{Durability}

Durability results are shown in Table 6.

Tabela 6: Durability

\begin{tabular}{cc}
\hline Treatments & $\boldsymbol{D U}(\%)$ \\
\hline B1 & $97.48 \pm 0.12 \mathrm{ab}$ \\
B2 & $97.71 \pm 0.15 \mathrm{ab}$ \\
B3 & $97.77 \pm 0.02 \mathrm{ab}$ \\
B4 & $97.16 \pm 0.12 \mathrm{bc}$ \\
B5 & $96.75 \pm 0.17 \mathrm{c}$ \\
B6 & $97.92 \pm 0.13 \mathrm{a}$
\end{tabular}

Different letters show significant difference between samples with 5\% significance in Tukey test.

Durability measures how the fuel behaves throughout transport and handling [35]. Good fuel for transportation has a durability greater than 90\% (Bajwa et al., 2018, Temmerman et al., 2006). Gendek et al.[52] obtained a briquette durability of $97.87 \%$ for Picea abies

Table 6 shows that all briquettes had durability close to 97\%. The values are high and guarantee the mechanical resistance of the briquettes during transport and handling. 


\subsection{Scanning electron microscopy (SEM) and energy dispersive spectroscopy (EDS)}

Scanning electron microscopy (SEM) and energy dispersive spectroscopy (EDS) results are presented in Figure 2.
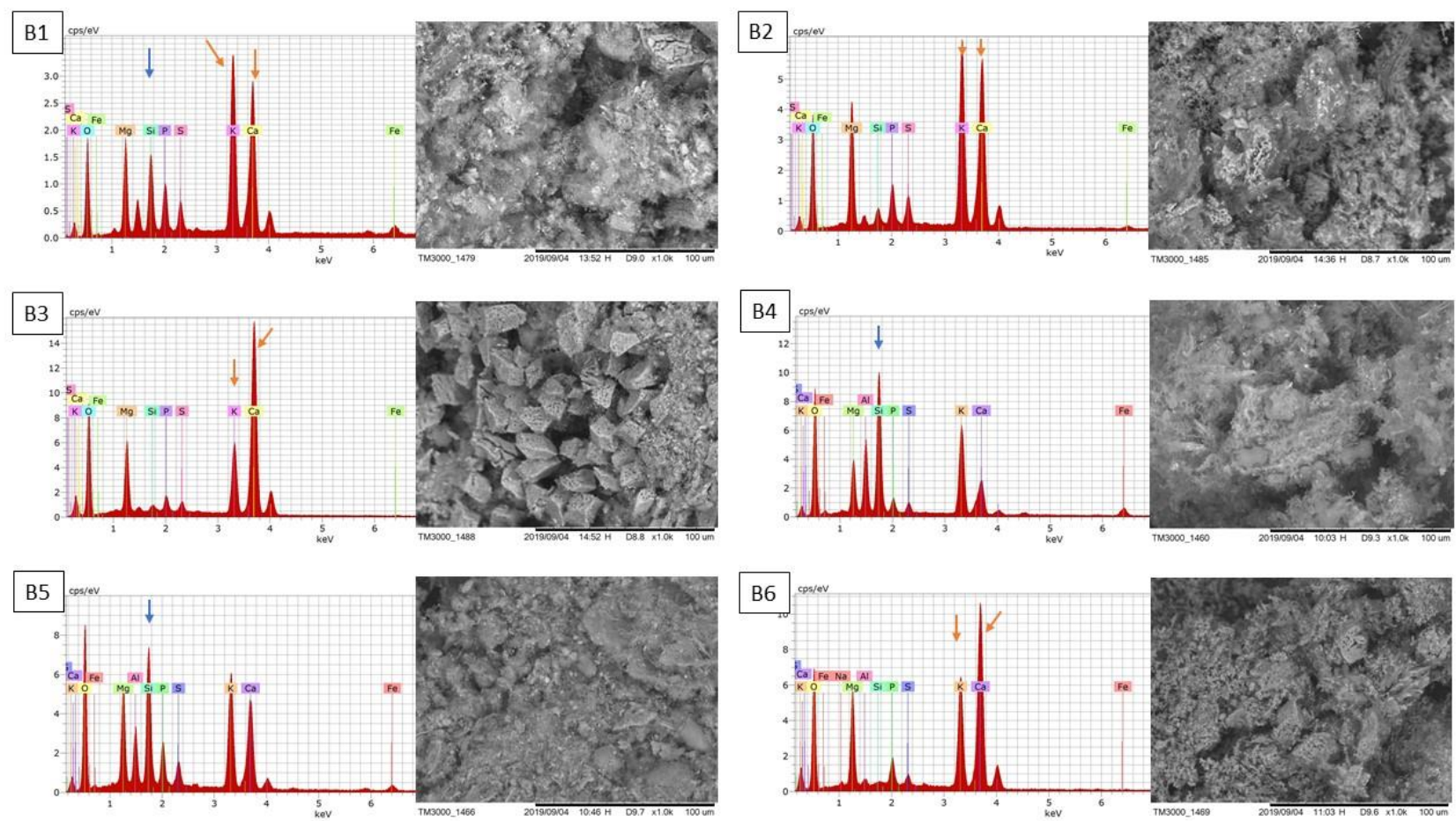

Figure 2. SEM-EDS surface and elemental composition of the studied treatments.

According to Nakashima et al. [53], biomass has inorganic components in its composition, such as calcium, potassium, magnesium, phosphorus, iron and zinc. But also, these and other minerals can be found during the biomass characterization, resulting in contaminants related to the soil. The inorganic elements present in biomass can cause incrustations and slags in equipment that use biomass. In Fig. 2, the EDS spectra identified the elements that compose each sample. The blends B1, B2, B3 and B6 presented a high amount of $\mathrm{K}$ and Ca, whereas B4 and B5 presented a high amount of Si. B1 presents $\mathrm{K}, \mathrm{Ca}$, and an indication of silica's presence in its composition because it presents 50\% sugarcane bagasse and straw, which are materials have more significant quantities of silica in the composition of their briquettes of 100\% (B4 and B5). According to Nakashima et al. 2017, silica is an element that appears in large quantities in sugarcane individuals. This element helps in its structure and gives rigidity to the plant; there is also a percentage related to contaminants due to the type of harvest, storage, and management of materials. 


\section{CONCLUSION}

- Raw cassava rhizomes can be used as natural binders in the formation of briquettes from mixtures of bagasse and sugarcane straw;

- The use of 75\% raw cassava rhizome (B2) produced briquettes $39 \%$ more resistant than briquettes of pure bagasse and $135 \%$ more resistant than pure straw briquettes;

- Energetic densification in the briquetting of bagasse, sugarcane straw, and cassava rhizome was 6.46.7 times greater than the energy density in the natural material (bulk density);

- All the briquettes presented excellent durability (97\%);

- The blends (B1, B2 and B3) can be used for briquette production. according to the availability of materials.

\section{ACKNOWLEDGEMENTS}

The authors are grateful to the São Paulo Research Foundation (FAPESP) [Grant \#2018/14827-8 and \#2018/11837-2] and the Coordenação de Aperfeiçoamento de Pessoal de Nível Superior - Brasil (CAPES) [Finance Code 001] for financially supporting our study.

\section{DECLARATIONS}

\section{Funding}

The authors are grateful to the São Paulo Research Foundation (FAPESP) [Grant \#2018/14827-8 and \#2018/11837-2] and the Coordenação de Aperfeiçoamento de Pessoal de Nível Superior - Brasil (CAPES) [Finance Code 001] for financially supporting our study.

\section{Conflicts of interest/Competing interests}

The authors declare that they have no known competing financial interests or personal relationships that could have appeared to influence the work reported in this paper.

\section{Availability of data and material}

The datasets generated during and/or analysed during the current study are available from the corresponding author on reasonable request.

\section{Code availability}

The authors declare that they have no code availability to influence the work reported in this paper. 


\section{Authors' contributions}

1-Andrea Cressoni De Conti - Conceptualization, Investigation, Supervision, Project administration, Formal analysis, Funding acquisition;

2-Marcos Paulo Patta Granado - Investigation, Funding Acquisition;

3- Elias Ricardo Durango Padilla - Investigation;

4- Gabriela Tami Nakashima - Investigation;

5 - Cláudio De Conti - Investigation;

6-Fabio Minoru Yamaji-Resources.

Ethics approval (include appropriate approvals or waivers)

Not Apply

Consent to participate (include appropriate statements)

Not Apply

Consent for publication (include appropriate statements)

Not Apply

\section{REFERENCES}

[1] J. Goldemberg and O. Lucon, “no Brasil,” Estud. Avançados, vol. 21, no. 59, pp. 7-20, 2007, doi: 10.1590/S0103-40142007000100003.

[2] F. Bilgili, E. Koçak, Ü. Bulut, and S. Kuşkaya, "Can biomass energy be an efficient policy tool for sustainable development?," Renew. Sustain. Energy Rev., vol. 71, no. December 2016, pp. 830-845, 2017, doi: 10.1016/j.rser.2016.12.109.

[3] C. P. Massola and E. Maziero, "Cenário brasileiro da geração e uso de biomassa adensada," Rev. [IPT] Tecnol. e Inovação, vol. 1, no. 4, pp. 58-73, 2017.

[4] J. P. S. Veiga, T. L. Valle, J. C. Feltran, and W. A. Bizzo, "Characterization and productivity of cassava waste and its use as an energy source,” Renew. Energy, vol. 93, pp. 691-699, 2016, doi: 10.1016/j.renene.2016.02.078.

[5] N. S. L. Srivastava, S. L. Narnaware, J. P. Makwana, S. N. Singh, and S. Vahora, "Investigating the energy use of vegetable market waste by briquetting," Renew. Energy, vol. 68, pp. 270-275, 2014, doi: 10.1016/j.renene.2014.01.047. 
[6] D. A. Da Silva, F. M. Yamaji, J. L. De Barros, A. L. Da Róz, and G. T. Nakashima, “Caracterização de biomassas para a briquetagem," Floresta, vol. 45, no. 4, pp. 713-722, 2015, doi: 10.5380/rf.v45i4.39700.

[7] M. de M. e Energia, “Em 2016, biomassa é a segunda maior fonte de energia,” 13/03/2017, pp. 20162017, 2017.

[8] Conab - Companhia Nacional do Abastecimento, “ACOMPANHAMENTO DA SAFRA

BRASILEIRA - Cana de Açúcar,” V. 7 - SAFRA 2020/21 N.2 - Segundo Levant. - Agosto 2020, 2020.

[9] M. A. Brand, Energia de Biomassa Florestal, 1st ed. Rio de Janeiro, 2010.

[10] L. A. H. Nogueira and E. E. S. Lora, Dendroenergia: Fundamentos e aplicações, 2 ed. Rio de Janeiro: Interciência, 2003.

[11] I. Niedziółka et al., "Assessment of the energetic and mechanical properties of pellets produced from agricultural biomass," Renew. Energy, vol. 76, pp. 312-317, 2015, doi: 10.1016/j.renene.2014.11.040.

[12] Y. Shiferaw et al., "Preparation and evaluation of clean briquettes from disposed wood wastes," Energy Sources, Part A Recover. Util. Environ. Eff., vol. 39, no. 20, pp. 2015-2024, 2017, doi: $10.1080 / 15567036.2017 .1399175$.

[13] I. Niedziółka et al., "Assessment of the energetic and mechanical properties of pellets produced from agricultural biomass," Renew. Energy, 2015, doi: 10.1016/j.renene.2014.11.040.

[14] L. A. B. Cortez, E. E. S. L. Lora, and E. O. Gómez, Biomassa para energia. campinas, 2008.

[15] D. S. Bajwa, T. Peterson, N. Sharma, J. Shojaeiarani, and S. G. Bajwa, "A review of densified solid biomass for energy production,” Renew. Sustain. Energy Rev., vol. 96, no. June, pp. 296-305, 2018, doi: 10.1016/j.rser.2018.07.040.

[16] S. Clarke, P. Eng, and F. Preto, "Biomass Densification for Energy Production. ORDER NO. 11-035 AGDEX 737/120,” no. 11, pp. 1-8, 2011.

[17] C. Antwi-Boasiako and B. B. Acheampong, "Strength properties and calorific values of sawdustbriquettes as wood-residue energy generation source from tropical hardwoods of different densities," Biomass and Bioenergy, vol. 85, pp. 144-152, 2016, doi: 10.1016/j.biombioe.2015.12.006.

[18] A. Yank, M. Ngadi, and R. Kok, "Physical properties of rice husk and bran briquettes under low pressure densification for rural applications," Biomass and Bioenergy, vol. 84, pp. 22-30, 2016, doi: 10.1016/j.biombioe.2015.09.015.

[19] E. R. D. Padilla, I. C. S. A. Pires, F. M. Yamaji, and J. M. M. Fandiño, "Production and PhysicalMechanical Characterization of Briquettes from Coconut Fiber and Sugarcane Straw," Rev. Virtual 
Química, vol. 8, no. 5, pp. 1334-1346, 2016, doi: 10.21577/1984-6835.20160095.

[20] F. F. Felfli, J. M. Mesa P, J. D. Rocha, D. Filippetto, C. A. Luengo, and W. A. Pippo, "Biomass briquetting and its perspectives in Brazil," Biomass and Bioenergy, vol. 35, no. 1, pp. 236-242, 2011, doi: 10.1016/j.biombioe.2010.08.011.

[21] L. Guo, L. G. Tabil, D. Wang, and G. Wang, "Influence of moisture content and hammer mill screen size on the physical quality of barley, oat, canola and wheat straw briquettes," Biomass and Bioenergy, vol. 94, pp. 201-208, 2016, doi: 10.1016/j.biombioe.2016.09.005.

[22] A. L. S. Hansted, G. T. Nakashima, M. P. Martins, H. Yamamoto, and F. M. Yamaji, “Comparative analyses of fast growing species in different moisture content for high quality solid fuel production," Fuel, vol. 184, pp. 180-184, 2016, doi: 10.1016/j.fuel.2016.06.071.

[23] M. Lubwama and V. A. Yiga, "Development of groundnut shells and bagasse briquettes as sustainable fuel sources for domestic cooking applications in Uganda,” Renew. Energy, vol. 111, pp. 532-542, 2017, doi: 10.1016/j.renene.2017.04.041.

[24] R. I. Muazu and J. A. Stegemann, "Effects of operating variables on durability of fuel briquettes from rice husks and corn cobs," Fuel Process. Technol., vol. 133, pp. 137-145, 2015, doi: 10.1016/j.fuproc.2015.01.022.

[25] S. A. Rahaman and P. A. Salam, "Characterization of cold densified rice straw briquettes and the potential use of sawdust as binder," Fuel Process. Technol., vol. 158, pp. 9-19, 2017, doi: 10.1016/j.fuproc.2016.12.008.

[26] R. Shuma and D. M. Madyira, "Production of Loose Biomass Briquettes from Agricultural and Forestry Residues,” Procedia Manuf., vol. 7, pp. 98-105, 2017, doi: 10.1016/j.promfg.2016.12.026.

[27] Z. Miao, P. Zhang, M. Li, Y. Wan, and X. Meng, "Briquette preparation with biomass binder," Energy Sources, Part A Recover. Util. Environ. Eff., vol. 00, no. 00, pp. 1-11, 2019, doi: $10.1080 / 15567036.2019 .1682722$.

[28] L. Florentino-Madiedo, E. Díaz-Faes, and C. Barriocanal, "Mechanical strength of bio-coke from briquettes," Renew. Energy, vol. 146, pp. 1717-1724, 2020, doi: 10.1016/j.renene.2019.07.139.

[29] R. I. Muazu and J. A. Stegemann, "Biosolids and microalgae as alternative binders for biomass fuel briquetting," Fuel, 2017, doi: 10.1016/j.fuel.2017.01.019.

[30] M. Lubwama and V. A. Yiga, "Characteristics of briquettes developed from rice and coffee husks for domestic cooking applications in Uganda," Renew. Energy, vol. 118, pp. 43-55, 2018, doi: 10.1016/j.renene.2017.11.003. 
[31] M. P. Granado et al., "Effects of pressure densi fi cation on strength and properties of cassava waste briquettes," Renew. Energy, no. xxxx, 2020, doi: 10.1016/j.renene.2020.11.087.

[32] G. Zhang, Y. Sun, and Y. Xu, "Review of briquette binders and briquetting mechanism," Renew. Sustain. Energy Rev., vol. 82, no. July 2017, pp. 477-487, 2018, doi: 10.1016/j.rser.2017.09.072.

[33] J. E. Gonçalves, M. M. P. Sartori, and A. L. Leão, "Energia de briquetes produzidos com rejeitos de resíduos sólidos urbanos e madeira de Eucalyptus grandis Energy from briquettes produced from remains of urban solid residues and wood of Eucalyptus grandis," Rev. Bras. Eng. Agrícola e Ambient., vol. 14, no. 5, pp. 657-661, 2009.

[34] T. Nurek, A. Gendek, K. Roman, and M. Dąbrowska, "Biomass and Bioenergy The effect of temperature and moisture on the chosen parameters of briquettes made of shredded logging residues," Biomass and Bioenergy, vol. 130, no. August, p. 105368, 2019, doi: 10.1016/j.biombioe.2019.105368.

[35] H. Gilvari, W. de Jong, and D. L. Schott, "Quality parameters relevant for densification of biomaterials: Measuring methods and affecting factors - A review,” Biomass and Bioenergy, vol. 120, no. October 2018, pp. 117-134, 2019, doi: 10.1016/j.biombioe.2018.11.013.

[36] ASTM D3173, "Standard Test Method for Moisture in the Analysis Sample of Coal and Coke," Statistics (Ber)., vol. 03, no. February 2008, pp. 1-3, 2013, doi: 10.1520/D3173-11.2.

[37] CEN/TS 15149-2, "Solid biofuels — Methods for the determination of particle size distribution," Management, vol. 3, 2005.

[38] ASTM D3175, "Standard Test Method for Moisture in the Analysis Sample of Coal and Coke," Statistics (Ber)., vol. 03, no. February 2008, pp. 1-3, 2013, doi: 10.1520/D3175-11.2.

[39] ASTM E873-13, "Standard test method for bulk density of densified particulate biomass fuels," 2013.

[40] ABNT NBR 7222, “NBR 7222: Argamassa e concreto - Determinação da resistência à tração por compressão diametral de corpos-de-prova cilíndricos," no. reapproved 2011, p. 3, 1994.

[41] W. Chrisostomo, “Estudo da compactação de Resíduos Lignocelulósicos para utilização como Combustível sólido,” Universidade Federal de São Carlos, Campus Sorocaba, 2011.

[42] J. M. Castellano, M. Gómez, M. Fernández, L. S. Esteban, and J. E. Carrasco, "Study on the effects of raw materials composition and pelletization conditions on the quality and properties of pellets obtained from different woody and non woody biomasses," Fuel, vol. 139, pp. 629-636, 2015, doi: 10.1016/j.fuel.2014.09.033.

[43] Y. Wang, K. Wu, and Y. Sun, "Effects of raw material particle size on the briquetting process of rice 
straw,” J. Energy Inst., vol. 91, no. 1, pp. 153-162, 2018, doi: 10.1016/j.joei.2016.09.002.

[44] K. G. Banaag, C. J. L. Navalta, and A. Von Raboy, "Solid Fuel from co-briquetting of Sugarcane Bagasse and Rice Bran Solid Fuel,” Accept. Manuscr., vol. 147, pp. 1941-1958, 2018, doi: 10.1016/j.renene.2019.09.129.

[45] O. . Obi, C. . Akubuo, and V.. Nwankwo, "Development of an Appropriate Briquetting Machine for Use in Rural Communities," Int. J. Eng. Adv. Technol., vol. 2, no. 4, pp. 578-582, 2013.

[46] J. L. Barros, “Caracterização De Blendas E Briquetes De Carvões Vegetal E Mineral,” p. 125, 2014.

[47] C. L. Mendoza Martinez, E. Sermyagina, A. de Cassia Oliveira Carneiro, E. Vakkilainen, and M. Cardoso, "Production and characterization of coffee-pine wood residue briquettes as an alternative fuel for local firing systems in Brazil," Biomass and Bioenergy, vol. 123, no. June 2018, pp. 70-77, 2019, doi: 10.1016/j.biombioe.2019.02.013.

[48] J. P. S. Veiga, "Caracterização de resíduos de c olheita da mandioca (Manihot esculenta CRANTZ) e avaliação do potencial de co- geração de energia no processo de produção de etanol,” p. 89, 2012.

[49] M. R. L. V. Leal, M. V. Galdos, F. V. Scarpare, J. E. A. Seabra, A. Walter, and C. O. F. Oliveira, “Sugarcane straw availability, quality, recovery and energy use: A literature review," Biomass and Bioenergy, vol. 53, pp. 11-19, 2013, doi: 10.1016/j.biombioe.2013.03.007.

[50] A. L. S. Hansted, T. A. Cacuro, G. T. Nakashima, V. E. Costa, H. Yamamoto, and F. M. Yamaji, "Use of a lignocellulosic residue as solid fuel: The effect of ash content in the energy potential," Ind. Crops Prod., 2018, doi: 10.1016/j.indcrop.2018.02.042.

[51] M. Temmerman, F. Rabier, P. D. Jensen, H. Hartmann, and T. Böhm, "Comparative study of durability test methods for pellets and briquettes," Biomass and Bioenergy, vol. 30, no. 11, pp. 964972, 2006, doi: 10.1016/j.biombioe.2006.06.008.

[52] A. Gendek, M. Aniszewska, J. Malat’ák, and J. Velebil, "Evaluation of selected physical and mechanical properties of briquettes produced from cones of three coniferous tree species," Biomass and Bioenergy, vol. 117, no. July, pp. 173-179, 2018, doi: 10.1016/j.biombioe.2018.07.025.

[53] G. T. Nakashima, M. P. Martins, A. L. S. Hansted, H. Yamamoto, and F. M. Yamaji, "Sugarcane trash for energy purposes: Storage time and particle size can improve the quality of biomass for fuel?," Ind. Crops Prod., 2017, doi: 10.1016/j.indcrop.2017.07.017. 


\section{Figures}

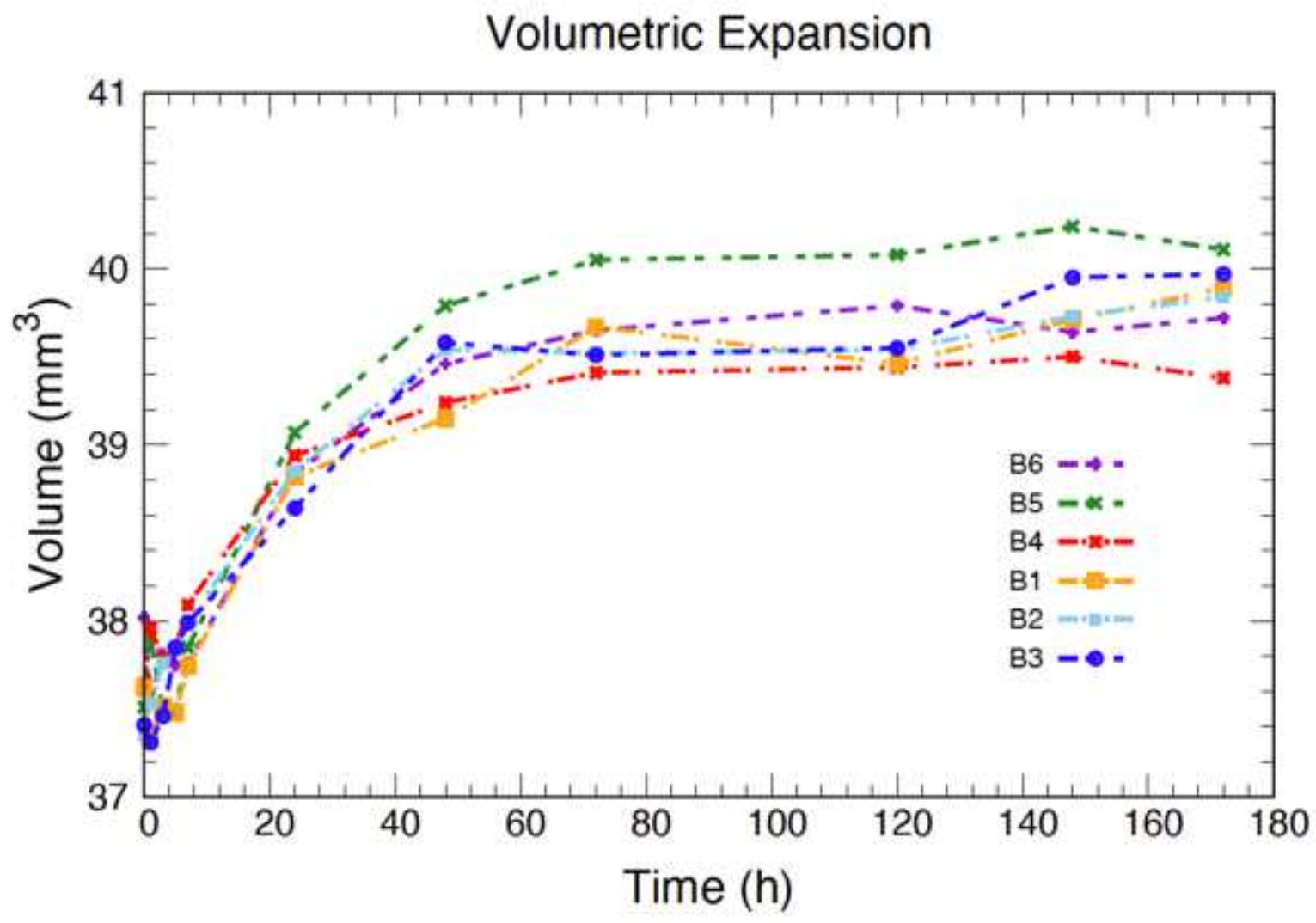

Figure 1

Volumetric Expansion of the briquettes formed by treatment.
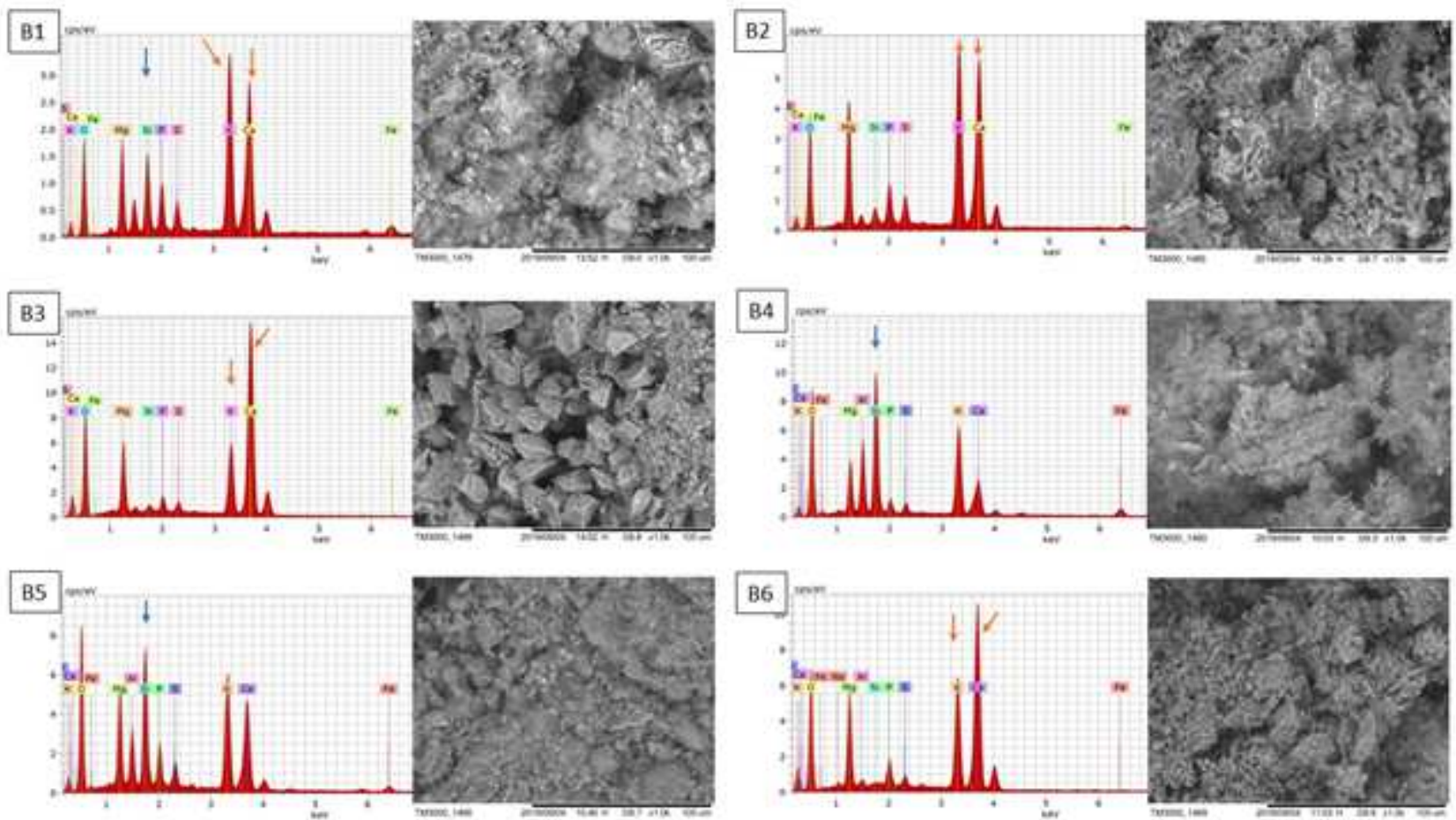
Figure 2

SEM-EDS surface and elemental composition of the studied treatments.

\section{Supplementary Files}

This is a list of supplementary files associated with this preprint. Click to download.

- highlightsrevisto.docx 